University of Nebraska - Lincoln

DigitalCommons@University of Nebraska - Lincoln

1987

\title{
Concentration of Maize Chlorotic Mottle Virus Increased in Mixed Infections with Maize Dwarf Mosaic Virus, Strain B
}

Karen-Beth Goldberg

University of Nebraska-Lincoln

Myron K. Brakke

University of Nebraska-Lincoln

Follow this and additional works at: https://digitalcommons.unl.edu/plantpathpapers

Part of the Plant Pathology Commons

Goldberg, Karen-Beth and Brakke, Myron K., "Concentration of Maize Chlorotic Mottle Virus Increased in Mixed Infections with Maize Dwarf Mosaic Virus, Strain B" (1987). Papers in Plant Pathology. 177.

https://digitalcommons.unl.edu/plantpathpapers/177

This Article is brought to you for free and open access by the Plant Pathology Department at DigitalCommons@University of Nebraska - Lincoln. It has been accepted for inclusion in Papers in Plant Pathology by an authorized administrator of DigitalCommons@University of Nebraska - Lincoln. 
Etiology

\title{
Concentration of Maize Chlorotic Mottle Virus Increased in Mixed Infections with Maize Dwarf Mosaic Virus, Strain B
}

\author{
Karen-Beth Goldberg and Myron K. Brakke
}

Agricultural Research Service, U.S. Department of Agriculture and Department of Plant Pathology, Nebraska Agricultural Experiment Station. University of Nebraska, Lincoln, 68583. Present address of first author: Plant Pathology Department, University of Kentucky, Lexington, 40546.

Cooperative investigation of the ARS, USDA, and the Nebraska Agricultural Experiment Station. Research conducted under project 21-3, and published as Journal Series Paper 7939 of the Nebraska Agricultural Experiment Station.

Mention of a trademark or proprietary product does not constitute a guarantee or warranty by the U.S. Department of Agriculture and does not imply approval to the exclusion of other products that may also be suitable.

The assistance and advice concerning the ELISA technique provided by Drs. Ellen Ball and Manuel Palomar are gratefully acknowledged. Accepted for publication 18 June 1986 (submitted for electronic processing).

\begin{abstract}
Goldberg, K.-B., and Brakke, M. K. 1987. Concentration of maize chlorotic mottle virus increased in mixed infections with maize dwarf mosaic virus, strain B. Phytopathology 77:162-167.

The concentration of maize chlorotic mottle virus (MCMV) was up to 5.4 times higher in plants infected with both MCMV and maize dwarf mosaic virus, strain B (MDMV-B), than in plants infected with MCMV only. The concentration of MDMV-B was the same in doubly and singly

chlorophyll and a lower than normal ratio of chloroplast to cytoplasmic rRNA. Purified MCMV had an extinction coefficient of $6.7 \mathrm{~cm}^{2} \mathrm{mg}^{-1}$ at 260 $\mathrm{nm}$, an absorption maximum at $258 \mathrm{~nm}$, minimum at $240 \mathrm{~nm}$, and $25 \%$ RNA.
\end{abstract} infected plants. Plants infected with both viruses had a reduced level of

Additional key words: corn lethal necrosis, Zea mays.
In the United States, a combination of maize chlorotic mottle virus (MCMV) and wheat streak mosaic virus (WSMV) or maize dwarf mosaic virus (MDMV), strain A or B, causes a disease known as corn lethal necrosis (CLN) (30). In fields with CLN, yield losses of up to $90 \%$ (24) have been reported in north central Kansas and south central Nebraska, where the disease is currently confined despite the fact that all three viruses have different aerial vectors $(6,23,26)$.

MCMV is a spherical ssRNA $(1.47 \mathrm{MDa})$ virus with a capsid protein of $24.6 \mathrm{kDa}(22)$. It is readily transmitted mechanically and, experimentally, by six species of chrysomelid beetles $(18,23)$. MDMV-B (26), an aphid-transmitted potyvirus, has a capsid protein of $35 \mathrm{kDa}$, an inclusion body protein of $66 \mathrm{kDa}(19)$, and a ssRNA of $3 \mathrm{MDa}$ (17). WSMV is a mite-transmitted, 700-nm flexuous rod with a capsid protein of $45 \mathrm{kDa}$, an inclusion body protein of $66 \mathrm{kDa}(9)$, and a ssRNA of $2.8 \mathrm{MDa}(6)$.

Plants with CLN show severe yellowing of leaves, which develops into necrosis beginning at the tips and edges of the leaves and progressing inward. Plants of many corn lines, particularly inbreds, develop a severe, often fatal disease if they become doubly infected when young.

The primary goal of this study was to determine if the concentrations of MCMV and MDMV-B were higher in plants with mixed infections than in those with single infections. The effect of

The publication costs of this article were defrayed in part by page charge payment. This article must therefore be hereby marked "advertisement" in accordance with 18 U.S.C. $\$$ 1734 solely to indicate this fact.

This article is in the public domain and not copyrightable. It may be freely reprinted with customary crediting of the source. The American Phytopathological Society, 1987. the disease on chloroplast and cytoplasmic rRNAs, a biochemical index of cell damage, is also reported because this information was available as a byproduct of the MCMV assay.

A preliminary report of these results has appeared (14).

\section{MATERIALS AND METHODS}

Viruses. To eliminate possible contaminants, the MCMV stock isolate was obtained from plants inoculated with a solution removed from the virus zone of a sucrose gradient and diluted to near the dilution end point. MDMV-B (type strain) was obtained from $\mathrm{S}$. Jensen of this department. The viruses were propagated on maize inbred $\mathrm{B} 73 \mathrm{Ht}$ plants grown in a greenhouse. $\mathrm{B} 73 \mathrm{Ht}$ is moderately susceptible to CLN and has ranked as more susceptible than $60 \%$ of inbreds tested in the NCR2 regional uniform inbred nursery over the last 5 yr (Brakke, unpublished data). To reduce the chances of contamination, virus cultures were started anew at monthly intervals from dried leaves kept over $\mathrm{CaCl}_{2}$ at $4 \mathrm{C}$. Five plants $(\mathrm{B} 73 \mathrm{Ht})$ were grown per $10-\mathrm{cm}$ pot, inoculated by leaf rubbing 10-12 days after planting when they were in the early three-leaf stage, and harvested 6, 10, and 15 days after inoculation. Sap from virus-infected leaves was used for inoculum after dilution in water to about 1:5 for MDMV-B and 1:15 for MCMV and addition of a few percent Celite.

MCMV purification. Infected leaves were harvested 12-15 days after inoculation and ground in $0.1 \mathrm{M} \mathrm{K}_{2} \mathrm{HPO}_{4}(1 \mathrm{~g}$ per $3 \mathrm{ml})$ in a blender for $2 \mathrm{~min}$. The extract was filtered through cheesecloth and centrifuged in a Beckman J21 B centrifuge with a JA20 rotor for 5 min at $8,000 \mathrm{rpm}$ at $5 \mathrm{C}$. One-molar $\mathrm{CaCl}_{2}$ (1/50 volume) was added to the supernatant, which was stirred for $20 \mathrm{~min}$, and then 
centrifuged for $10 \mathrm{~min}$ at $10,000 \mathrm{rpm}$. After addition of Triton X-100 to $2 \%$, the supernatant was floated on a pad of $20 \%$ sucrose in $0.01 \mathrm{M}$ sodium acetate, $\mathrm{pH} 6.0$ (buffer $\mathrm{A}$ ), and centrifuged for $2.5 \mathrm{hr}$ at $28,000 \mathrm{rpm}$ in a Beckman Type 30 rotor. The pellet was suspended in buffer $\mathrm{A}$ and clarified by centrifugation for $10 \mathrm{~min}$ at $10,000 \mathrm{rpm}$. The supernatant $(2-4-\mathrm{ml}$ aliquots $)$ was floated on sucrose gradients $(5,9,9$, and $9 \mathrm{ml}$ of $100,200,300$, and $400 \mathrm{mg}$ of sucrose per milliliter) in buffer A and centrifuged for $2.5 \mathrm{hr}$ at $25,000 \mathrm{rpm}$, at $5 \mathrm{C}$ in the Beckman SW28 rotor. The virion zone was removed with a bent needle and syringe and placed on a second gradient $(5,9,9$, and $9 \mathrm{ml}$ of $300,400,500$, and $600 \mathrm{mg}$ of sucrose per milliliter in buffer A) and centrifuged for $14-16 \mathrm{hr}$ at 25,000 rpm at $5 \mathrm{C}$. The virion zone was collected and dialyzed against 0.01 $\mathrm{M}$ sodium acetate, $\mathrm{pH} 6.0$, with $1 \mathrm{mM} \mathrm{MgCl} 2$ (buffer $\mathrm{B}$ ) and $0.05-0.1 \%$ chloroform. Virions were pelleted by high-speed centrifugation and suspended in buffer B. Ultraviolet absorption spectra were determined on portions of these virus preparations and other portions were dried to constant weight at $80 \mathrm{C}$ in a vacuum oven.

Spectral analysis. Absorbances were determined in a Cary Model 14 recording spectrophotometer. For RNA determination, one $A_{260 \mathrm{~nm}}$ unit of purified MCMV per milliliter was incubated for $12 \mathrm{hr}$ at $25 \mathrm{C}$ in $1 \mathrm{M} \mathrm{HCl}(8)$ and centrifuged for $10 \mathrm{~min}$ at 10,000 $\mathrm{rpm}$. The supernatant was hydrolyzed RNA. The pellet contained protein which was washed with $1 \mathrm{M} \mathrm{HCl}$, suspended in buffer $\mathrm{A}$ with $1 \%$ sodium dodecyl sulfate (SDS), heated a few minutes at 60-100 C, and used for spectrophotometry. The absorbance of the virions both in buffer $\mathrm{A}$ and after disruption in buffer A with $1 \%$ SDS was also determined. Difference spectra were determined with native virions in the sample cell and SDS-disrupted virions in the reference cell (8).

Viral RNA and rRNA assays. The third leaf from the base and the terminal leaf were harvested from 10-15 plants at 6,10 , and 15 days after inoculation with water only, MCMV, MDMV-B, or MCMV plus MDMV-B. The terminal leaf is defined as the youngest leaf that was at least two-thirds expanded. This was leaf 4 at 6 days, leaf 4 or 5 at 10 days, and leaf 5 or 6 at 15 days after inoculation. Leaves were stored in plastic bags at $4 \mathrm{C}$ until assayed within 2 days. Terminal and third leaves were assayed separately. Leaves were cut into $0.5-\mathrm{cm}$ segments and $1 \mathrm{-g}$ samples were ground for $2 \mathrm{~min}$ in a cold mortar and pestle in $20 \mathrm{ml}$ of buffer $\mathrm{C}(0.1 \mathrm{M}$ $\left(\mathrm{NH}_{4}\right)_{2} \mathrm{CO}_{3}, 0.3 \mathrm{M} \mathrm{NH}_{4} \mathrm{Cl}, 1 \mathrm{mM}$ EDTA, and $1 \% \mathrm{SDS}$, adjusted to $\mathrm{pH} 9.3$ with $\mathrm{NaOH}$ (7). The extract was filtered through Miracloth (Calbiochem Corp.) and centrifuged for $10 \mathrm{~min}$ at $10,000 \mathrm{rpm}$ in the Beckman JA20 rotor. After addition of Triton X-100 to a final concentration of $1 \%$, a $200-\mu \mathrm{l}$ sample of the supernatant (corresponding to $9.5 \mathrm{mg}$ of tissue) was layered on a gradient composed of $0.5,1.1,1.1$, and $1.1 \mathrm{ml}$ of $75,150,225$, and $300 \mathrm{mg}$ of sucrose per milliliter of NaGPS buffer $\left(0.05 \mathrm{M} \mathrm{Na}_{2} \mathrm{HPO}_{4}, 0.3 \mathrm{M}\right.$ $\mathrm{NaCl}, 0.1 \mathrm{M}$ glycine, and $1 \mathrm{mM}$ EDTA, $\mathrm{pH} 9.4)$ (12) and centrifuged for $3 \mathrm{hr}$ at $54,000 \mathrm{rpm}$ at $15 \mathrm{C}$ in the Beckman SW60 rotor. Each extract was analyzed on two gradients. The gradients were scanned with an ISCO Model UA-5 densitometer. Areas of the peaks were measured with a planimeter and converted to milligrams of RNA per gram of leaf tissue assuming an $A_{260 \mathrm{~nm}}$ of 25 for $1 \mathrm{mg}$ of RNA per milliliter $(4,5)$. Experiments were repeated three times. Each experiment included triplicate sets of 10-15 plants from which leaves were harvested and assayed separately. Leaves were cut into segments and randomly selected portions were assayed for MCMV-RNA plus rRNA, MDMV-B by ELISA, and chlorophyll.

Viral RNA infectivity. Gradient column purified MCMV RNA was diluted 1:1 in $0.05 \mathrm{M} \mathrm{K}_{2} \mathrm{HPO}_{4}, 0.05 \mathrm{M}$ glycine ( $\mathrm{pH} 9.0$ ), $100 \mu \mathrm{g}$ of bentonite per milliliter (buffer D), and a few percent Celite and rubbed on corn plants in the five-leaf stage (7). Symptoms were noted 15 days after inoculation and the presence of the virus was confirmed by partial purification and SDS-polyacrylamide gel electrophoresis (SDS-PAGE) of the viral protein (21).

ELISA. Leaves of MDMV-B and doubly infected plants as described above were ground for $2 \mathrm{~min}$ in $0.01 \mathrm{M}$ phosphate, $\mathrm{pH}$ $7.0(1 \mathrm{~g}$ per $10 \mathrm{ml})$, with a mortar and pestle. The extract was cBublishegd dn BHIVTAPATH removed. Dilutions were made in phosphate buffer in twofold steps from 1:100 to 1:12,800. ELISA was performed as described by Clark and Adams (11) with the modifications of Jensen et al (20). Nunc brand microtiter plates were coated with $\mathrm{IgG}$ from antiserum to MDMV-B at a concentration of $2 \mu \mathrm{g} / \mathrm{ml}$. EnzymeIgG conjugate was used at $1 \mu \mathrm{g} / \mathrm{ml}$. MDMV-B antiserum, IgG, and IgG-alkaline phosphatase conjugate were prepared by M. K. Palomar. A standard curve was established for each set of assays with purified MDMV-B.

Chlorophyll assay. Leaf samples of $0.2 \mathrm{~g}$ were ground in $5 \mathrm{ml}$ of aqueous $80 \%$ acetone in a mortar and pestle for $1 \mathrm{~min}$ and diluted to a final volume of $20 \mathrm{ml}(1: 100)$ with aqueous $80 \%$ acetone. The extract was centrifuged for $10 \mathrm{~min}$ at $10,000 \mathrm{rpm}$ at $5 \mathrm{C}$ and the absorbance of the supernatant was measured on a Cary Model 14 recording spectrophotometer at $663 \mathrm{~nm}$ (chlorophyll a) and 645 $\mathrm{nm}$ (chlorophyll b). The concentration of chlorophyll a and chlorophyll $\mathrm{b}$ were converted to milligrams of chlorophyll per gram of leaf tissue (2).

\section{RESULTS}

MCMV purification. The extinction coefficient and RNA content of MCMV were determined after purification so that the results of subsequent assays could be expressed per weight of virus. Numerous clarification procedures were tested to optimize the removal of plant components. These procedures were tested on small samples $(1 \mathrm{~g})$ of leaf tissue and the results were assessed by analytical density gradient centrifugation. Yields and virion purity were always considerably reduced when these procedures were scaled up for larger quantities. The procedure selected gave the best and most consistent yields for larger amounts of tissue. Concentrations of virus at each purification step were determined by analytical density gradient centrifugation assay of the RNA released on suspending virions in $0.3 \mathrm{M}$ potassium acetate, $\mathrm{pH} 8.0$, and $1 \%$ SDS for $30 \mathrm{~min}$. Based on this assay, approximately $70 \%$ of the virions were recovered after the first high-speed centrifugation, $40 \%$ after the first $(10-40 \% \mathrm{w} / \mathrm{v})$ sucrose gradient, and $20 \%$ after the second $(30-60 \% \mathrm{w} / \mathrm{v})$ sucrose gradient.

Purified virus had only traces of host protein as detected by Coomassie blue staining after SDS-PAGE $(50 \mu \mathrm{g}$ of virion protein per gel lane). No host rRNA was detected in purified virions by either density gradient centrifugation or nondenaturing RNA gel electrophoresis (17). Approximately $80 \%$ of the total RNA present in purified virions was recovered in the genomic RNA zone after density gradient centrifugation (Fig. $1 \mathrm{E}$ and F); the remaining $20 \%$ was heterogeneous and presumably was genomic degradation products and subgenomic RNA, if such exists in MCMV (Fig. IE and F). Therefore, the weight of RNA recovered in the sucrose gradient was multiplied by five to give weight of virions.

Spectral analysis of MCMV. The extinction coefficient of purified MCMV was $6.7 \mathrm{~cm}^{2} \mathrm{mg}^{-1}$ at $260 \mathrm{~nm}$ (eight determinations, range 6.55 to 6.73 , average 6.66$), A_{260 / 280 n m}$ was $1.72, \lambda_{\max }$ was 258 $\mathrm{nm}$ and $\lambda_{\min }$ was $240 \mathrm{~nm}$ (Fig. 2). The reported base ratio of MCMV RNA (15) gives a calculated value of 33.9 for the $A_{260 \mathrm{~nm}}$ at $\mathrm{pH} \mathrm{2}$, based on the nucleotides present in $1 \mathrm{mg}$ of RNA per milliliter. From this value, dry-weight measurements, and the absorbance of hydrolyzed RNA after $1 \mathrm{M} \mathrm{HCl}$ treatment, MCMV contains $25 \%$ RNA, which agrees well with $25 \%$ RNA calculated from an assumed 180 protein subunits of $24.6 \mathrm{kDa}$ and one RNA of $1.47 \mathrm{MDa}$ (22). Samples of MCMV heated at $100 \mathrm{C}$ for $3 \mathrm{~min}$ in buffer A with $1 \%$ SDS showed little change in absorbance from untreated virus (Fig. 2). $\mathrm{HCl}$-precipitated protein dissolved in $1 \%$ SDS in buffer A had a small absorbance peak at $280 \mathrm{~nm}$. Difference spectra between intact virus and SDS-disrupted virus (Fig. 2) had small inflections at 286 and $295 \mathrm{~nm}$ indicating a small amount of aromatic amino acids.

Concentration of virus in single and mixed infections. Assays based on purified or partially purified MCMV virions were unreliable because of the low and erratic yields noted above. ELISA assays of MCMV preparations at successive dilutions gave inconsistent results, possibly due to disruption of virions at high dilution, which could not be interpreted as actual viral concentra- 
tions. The MCMV concentration was, therefore, determined by measuring viral RNA present in density gradients of whole cell RNA preparations. MCMV RNA sedimented faster than the cytoplasmic and chloroplast rRNAs and was easily detected in whole cell nucleic acid preparations (Fig. 3).

The concentration of MCMV genomic RNA resulting from single and mixed infections differed dramatically (Table 1, Fig. 4). The MCMV-infected third and terminal leaves had concentrations much lower than the corresponding CLN-infected leaves. Except for the third leaf 6 days after inoculation, the CLN-infected leaves had 1.7-5.4 times as much MCMV-RNA as did singly infected leaves. All MCMV-and CLN-infected leaves, except the MCMVinfected third leaf, had less MCMV RNA 15 days after inoculation than at 10 days.

There was no consistent difference between singly and doubly infected plants in the concentration of MDMV-B determined by

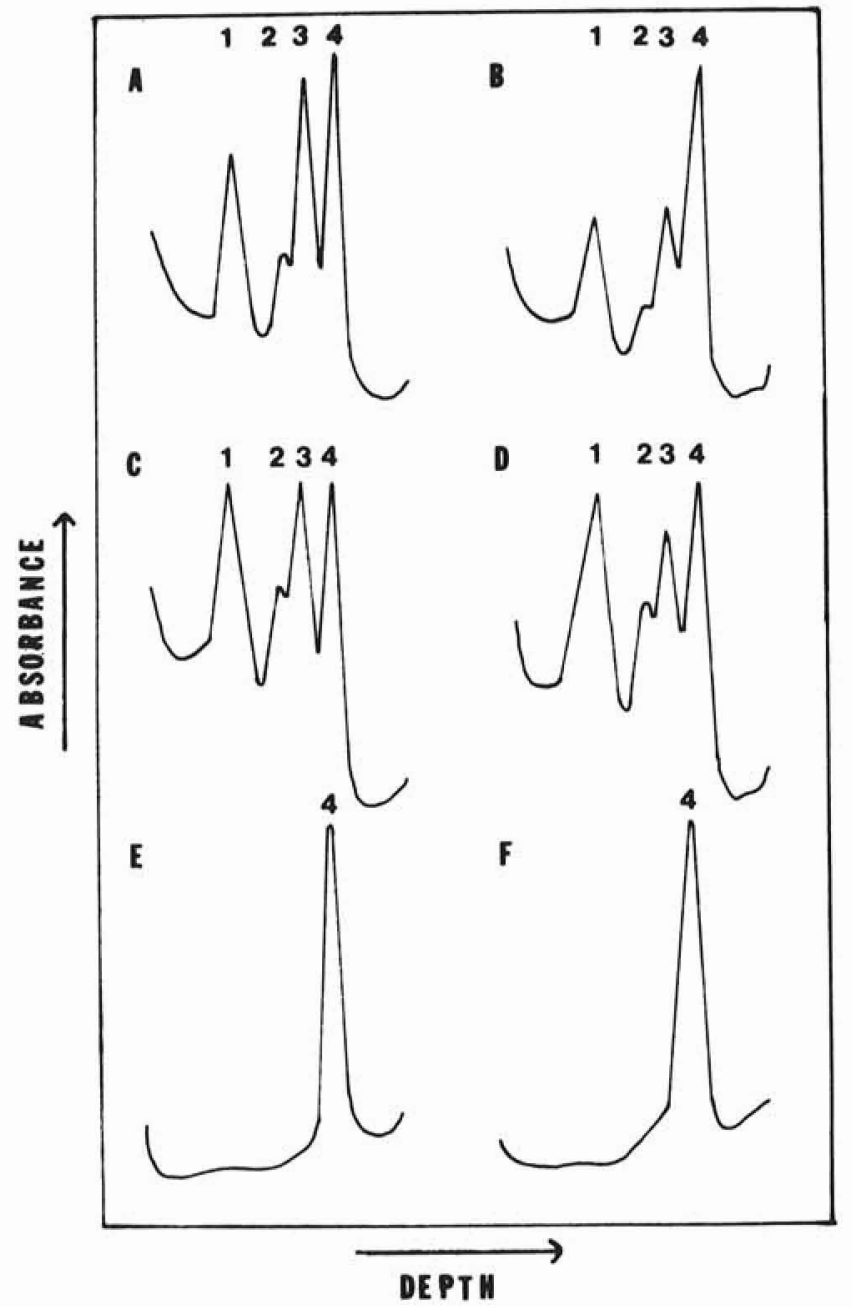

Fig. 1. Absorbance $(254 \mathrm{~nm})$ scans of centrifuged gradient columns with extracts of corn leaves or of purified maize chlorotic mottle virus (MCMV). The peaks are at depths expected for free ribosomal or viral RNA. Peak I represents the $16 \mathrm{~S}$ and $18 \mathrm{~S}$ rRNAs, peak 2 the $23 \mathrm{~S}$ rRNA, peak 3 the $28 \mathrm{~S}$ rRNA, and peak 4 the MCMV RNA. A. An extract of a doubly (corn lethal necrosis) infected plant in buffer $\mathrm{C}\left(0.1 \mathrm{M}\left(\mathrm{NH}_{4}\right)_{2} \mathrm{CO}_{3}, 0.3 \mathrm{M} \mathrm{NH} \mathrm{N}_{4} \mathrm{Cl}, 1 \mathrm{mM}\right.$ EDTA, $1 \%$ SDS pH 9.4). B. An extract of doubly infected plant in NaGPS buffer (0.3 M NaCl, $0.05 \mathrm{Na}_{2} \mathrm{HPO}_{4}, 0.1 \mathrm{M}$ glycine, $1 \mathrm{mM}$ EDTA, pH 9.4). C. An extract of healthy corn leaves with purified MCMV added during grinding in buffer C. D. An extract of healthy corn leaves with purified MCMV added during grinding in NaGPS. E. Purified MCMV diluted in buffer C. F. Purified MCMV diluted in NaGPS. The same amount of purified virus was present in samples placed on gradients $C, D, E$, and $F$, representing purified virus from five times the amount of leaf tissue placed on gradients A and B (demonstrating the loss of virions during purification). The area of the MCMV RNA peaks corresponds to 20, 19 , 20 , and $19 \mu \mathrm{g}$ virus for patterns $C, D, E$, and F, respectively. Centrifuged for $3 \mathrm{hr}$ at $54,000 \mathrm{rpm}$ at $15 \mathrm{C}$ in a $7.5-30 \%(\mathrm{~W} / \mathrm{v})$ sucrose gradient in a $S W 60$ Berbblishedt ir.PHYTOPATHOLOGY 77:2 (1987), pp. 162-167.
ELISA (Fig. 4). The concentrations of MDMV-B were 1.5-2.5 times higher 10 days after inoculation than 6 days after inoculation and fell slightly by 15 days after inoculation.

Extracts from MDMV-B-infected plants were partly purified and assayed by SDS-PAGE for inclusion body protein $(66 \mathrm{kDa})$ (19). There was no apparent change in concentration of the $66 \mathrm{kDa}$ protein in singly versus doubly infected plants (data not shown).

Effect of virus infection on rRNA and chlorophyll. There was little change in amounts of $23 \mathrm{~S}$ and $28 \mathrm{~S}$ rRNAs or in the $23 \mathrm{~S} / 28 \mathrm{~S}$ rRNA ratio of the MCMV and MDMV-B plants compared with healthy plants (Table 1). However, the amount of $23 \mathrm{~S}$ rRNA and the $23 \mathrm{~S} / 28 \mathrm{~S}$ rRNA ratio was usually reduced slightly in CLN-

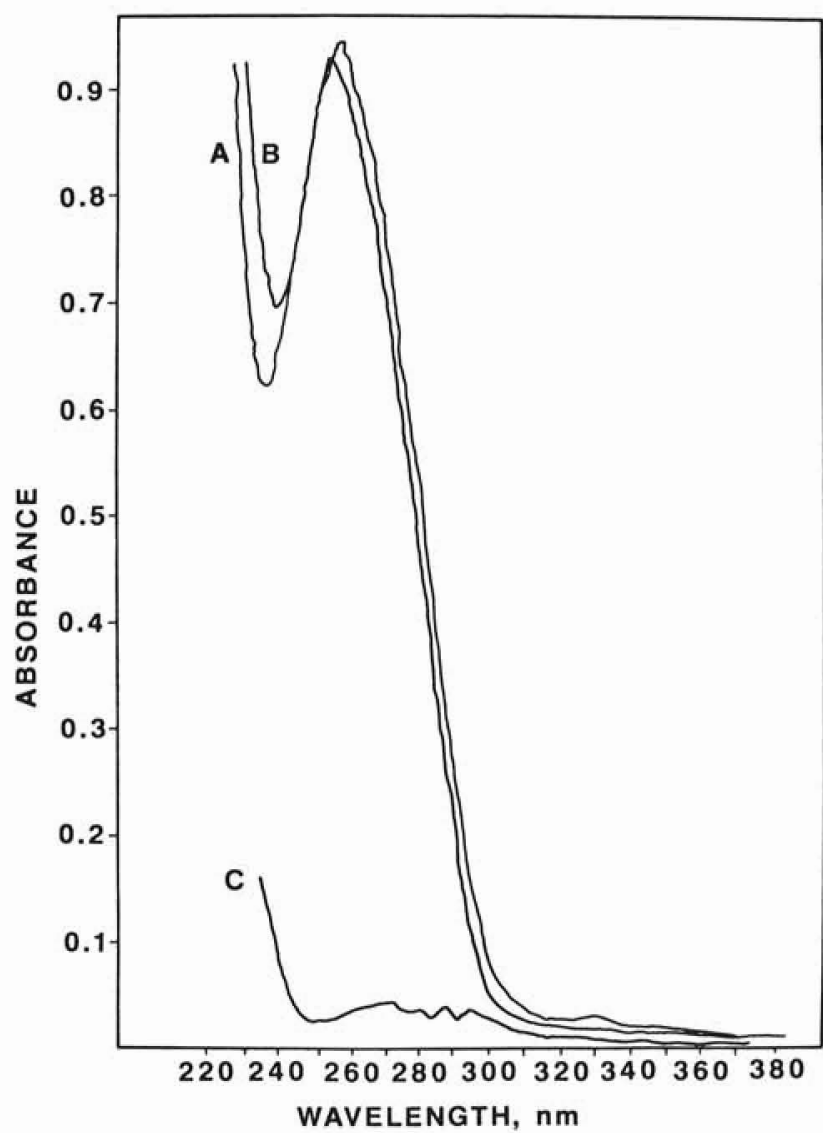

Fig. 2. Absorbance spectra of purified maize chlorotic mottle virus A, in buffer $\mathbf{B}$, after disruption in SDS, and $\mathbf{C}$, difference spectra.

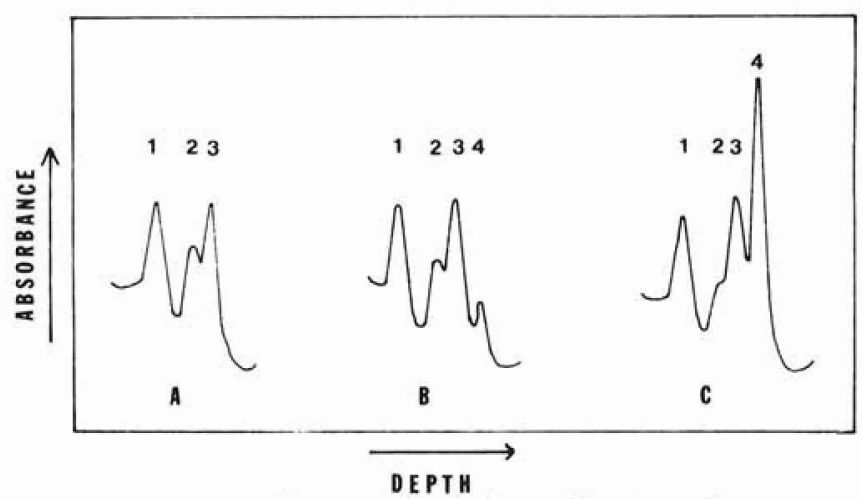

Fig. 3. Absorbance $(254 \mathrm{~nm})$ scans of centrifuged gradient columns containing nucleic acids from maize leaves that were $\mathbf{A}$, Uninfected, B, Infected with maize chlorotic mottle virus (MCMV), or C, With MCMV and maize dwarf mosaic virus, strain B, (MDMV-B) representing corn lethal necrosis. Each pattern has nucleic acid from $9.5 \mathrm{mg}$ of leaves. Centrifuged for $3 \mathrm{hr}$ at $54,000 \mathrm{rpm}$ at $15 \mathrm{C}$ in a $7.5-30 \%(\mathrm{w} / \mathrm{v})$ sucrose gradient in the Beckman SW60 rotor. Peak 1 represents the $16 \mathrm{~S}$ and $18 \mathrm{~S}$ rRNAs, peak 2 the $23 \mathrm{~S}$ (chloroplast) rRNA, peak 3 the $28 \mathrm{~S}$ (cytoplasmic) rRNA, and peak 4 the MCMV RNA. The concentration of MDMV-B RNA was too low to be detected on the gradient column in pattern $C$. 
infected plants. The occasional increase in concentration of $28 \mathrm{~S}$ rRNA on a wet weight basis does not mean that each cell had more $28 \mathrm{~S}$ rRNA because cells in infected leaves might have been smaller than in healthy leaves. The standard errors in the rRNA concentrations reflect primarily the variation from one experiment to another rather than variation in the duplicate density gradient centrifugation assays (Table 1).

A ratio of about $4: 1$ of chlorophyll a: chlorophyll b (milligram per gram of leaf tissue) was observed in all infected and uninfected leaves 6, 10, and 15 days after inoculation (data not shown). There was no reduction in chlorophyll in infected leaves 6 days after inoculation, but reductions were consistently found in infected leaves 10 and 15 days after inoculation, with the largest reduction $(50 \%)$ in CLN-infected terminal leaves 15 days after inoculation (Fig. 5).

MCMV-RNA infectivity. MCMV RNA recovered from sucrose gradients was infectious and plants infected with it had typical symptoms. Partial purification followed by SDS-PAGE of proteins confirmed the presence of MCMV virions in the RNA inoculated plants. The 10 -min thermal inactivation point of MCMV RNA was $85 \mathrm{C}$ in buffer $\mathrm{D}$.

Stability of MCMV. Tissue contained more viral RNA than could be accounted for in terms of virion yield. This could reflect

TABLE 1. Concentrations of ribosomal and maize chlorotic mottle virus (MCMV) RNAs in plants with MCMV only, with maize dwarf mosaic virus, strain B (MDMV-B), or with both viruses (corn lethal necrosis, CLN)

\begin{tabular}{|c|c|c|c|c|}
\hline \multirow{2}{*}{$\begin{array}{l}\text { Post-inoculation } \\
\text { day, leaf location, } \\
\text { and treatment }\end{array}$} & \multirow[b]{2}{*}{$23 \mathrm{~S}$ rRNA } & \multirow[b]{2}{*}{$28 \mathrm{~S}$ rRNA } & \multirow{2}{*}{$\begin{array}{l}23 \mathrm{~S} \text { rRNA } \\
28 \mathrm{~S} \text { rRNA }\end{array}$} & \multirow{2}{*}{$\begin{array}{c}\text { MCMV } \\
\text { RNA }\end{array}$} \\
\hline & & & & \\
\hline \multicolumn{5}{|l|}{ Day 6} \\
\hline \multicolumn{5}{|l|}{ Third leaf } \\
\hline Healthy & $0.19 \pm 0.01^{b}$ & $0.28 \pm 0.02$ & $0.68 \pm 0.03^{c}$ & 0.00 \\
\hline MCMV & $0.18 \pm 0.01$ & $0.29 \pm 0.03$ & $0.63 \pm 0.05$ & $0.02 \pm$ \\
\hline MDMV-B ${ }^{d}$ & 0.21 & 0.37 & $0.57 \pm 0.05$ & $\ldots$ \\
\hline CLN & $0.19 \pm 0.02$ & & $0.60 \pm 0.04$ & $02+8-4-4$ \\
\hline \multicolumn{5}{|l|}{ Terminal leaf } \\
\hline Healthy & $0.25 \pm 0.01$ & $0.45 \pm 0.03$ & $0.58 \pm 0.05$ & 0.00 \\
\hline M & 0.25 & $0.39=$ & $0.65 \pm 0.04$ & $0.03 \pm 0.01$ \\
\hline CLN & 2 & $0.46 \pm$ & $0.47 \pm 0.04$ & $0.07 \pm 0.03$ \\
\hline \multicolumn{5}{|l|}{ Day 10} \\
\hline \multicolumn{5}{|l|}{ Third leaf } \\
\hline Healthy & $0.14 \pm 0.02$ & 0.22 & 3 & 0.00 \\
\hline MCMV & $0.13 \pm 0.01$ & $0.22 \pm 0.02$ & $0.60 \pm 0.04$ & $0.07 \pm 0$ \\
\hline MDMV-B & $0.17 \pm 0.01$ & $0.27 \pm 0.02$ & $0.64 \pm 0.05$ & $\ldots$ \\
\hline CLN & $0.12 \pm 0.01$ & $0.27 \pm 0$ & $0.47 \pm 0.04$ & $0.18 \pm 0$. \\
\hline \multicolumn{5}{|l|}{ Terminal leaf } \\
\hline Healthy & 0.19 & 0.37 & 0.50 & 0.00 \\
\hline $\mathrm{MCN}$ & $0.19 \pm 0.02$ & $0.38 \pm 0.03$ & $0.51 \pm 0.03$ & $0.05 \pm 0$ \\
\hline MDMV-B ${ }^{d}$ & $0.19 \pm 0.00$ & $0.41 \pm 0.02$ & $0.45 \pm 0.02$ & $\cdots$ \\
\hline CLN & $0.14 \pm 0.01$ & $0.38 \pm 0$ & $0.38 \pm 0.03$ & $0.27 \pm 0$ \\
\hline \multicolumn{5}{|l|}{ Day 15} \\
\hline \multicolumn{5}{|l|}{ Third leaf } \\
\hline & $0.10 \pm 0.01$ & 0.17 & 0.65 & 0.00 \\
\hline MCMV & $0.10 \pm 0.01$ & $0.19 \pm 0.01$ & $0.55 \pm 0.05$ & $0.09 \pm 0$ \\
\hline MDMV-E & $0.13 \pm 0.02$ & $0.26 \pm 0.01$ & $0.50 \pm 0.06$ & $\cdots$ \\
\hline $\mathrm{CLN}^{t}$ & $0.10 \pm 0.01$ & $0.22 \pm 0.02$ & $0.41 \pm 0.03$ & $0.15 \pm 0$ \\
\hline \multicolumn{5}{|l|}{ Terminal leaf } \\
\hline Healthy & $0.20 \pm 0.02$ & $0.40 \pm 0.02$ & $0.51 \pm 0.05$ & 0.00 \\
\hline MCMV & $0.19 \pm 0.02$ & $0.35 \pm 0.03$ & $0.56 \pm 0.03$ & $0.04 \pm$ \\
\hline MDMV-B & $0.20 \pm 0.01$ & $0.46 \pm 0.03$ & $0.44 \pm 0.02$ & $\ldots$ \\
\hline CLN & $0.16 \pm 0.01$ & $0.33 \pm 0.03$ & $0.48 \pm 0.02$ & $0.19 \pm 0.05$ \\
\hline
\end{tabular}

${ }^{\text {a }}$ Concentrations given in milligrams of RNA per gram (wet weight) of leaf tissue.

'Mean and standard error of the mean for measurements made on three gradient columns for each of three experiments, except where specified otherwise.

'Mean and standard error of the mean of ratios calculated from areas of $23 \mathrm{~S}$ and $28 \mathrm{~S}$ rRNA peaks of each gradient.

${ }^{\text {"Values }}=$ mean and standard error of three measurements for one experiment.

${ }^{\text {CValues }}=$ mean and standard error of seven measurements for three experiments.

'Values $=$ mean and standard error of eight measurements for three expublished in PHYTOPATHOLOGY 77:2 (1987), pp. 162-167. degradation or loss of virions during purification or unencapsidated MCMV-RNA in infected cells. In an attempt to distinguish between these possibilities, extracts of infected leaves in NaGPS buffer were assayed for viral RNA. Many viruses, e.g., tobacco mosaic virus, southern bean mosaic virus, and barley stripe mosaic virus, are stable in $\operatorname{NaGPS}(7,12,25)$, whereas other

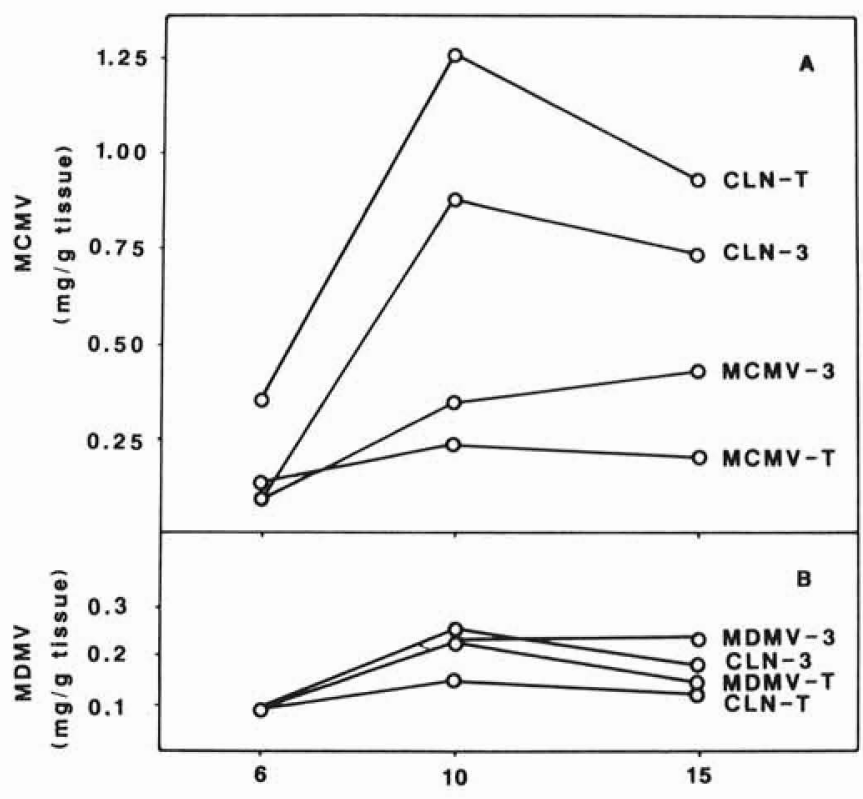

DAYS AFTER INOCULATION

Fig. 4. Concentration of virions in corn plants with single (MCMV or MDMV) or mixed infection (CLN). A. Concentration ( $\mathrm{mg} / \mathrm{g}$ wet weight) of maize chlorotic mottle (MCMV) calculated as five times the amount of viral genomic RNA measured by density gradient centrifugation analysis of total nucleic acid. B. Concentration of maize dwarf mosaic virus, strain B, (MCMV-B) measured by ELISA. Concentrations are given for leaf three $(-3)$ and the youngest or terminal (-T) leaf at 6,10 , and 15 days after inoculation.

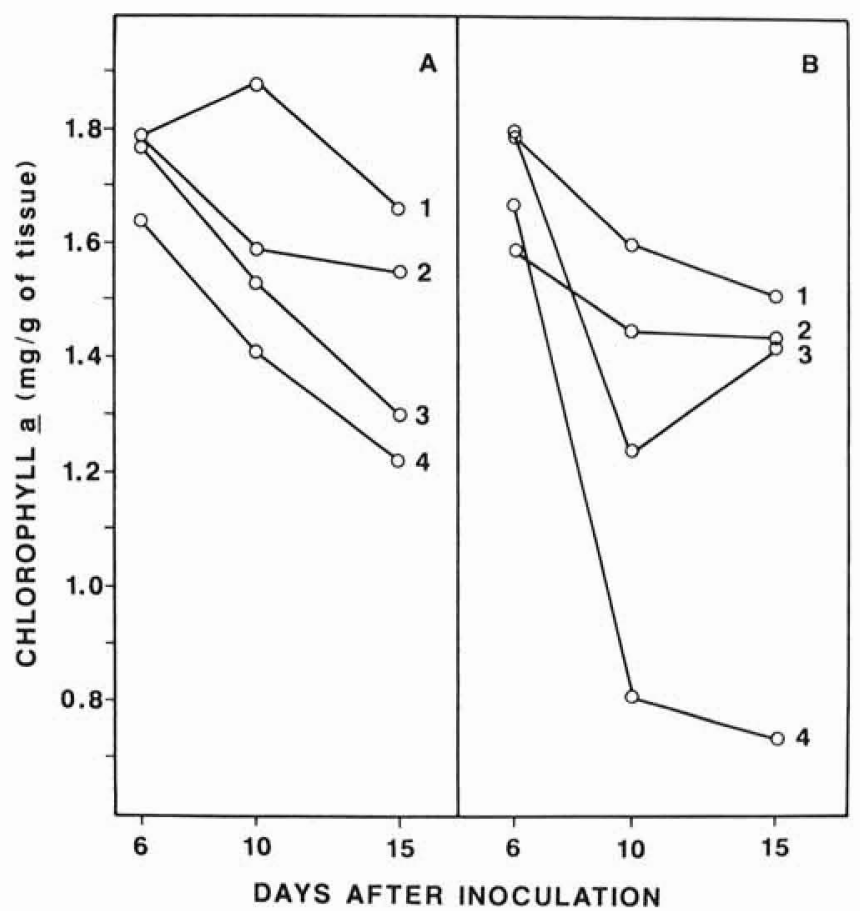

Fig. 5. Concentrations of chlorophyll a in milligrams per gram of leaf tissue for the third leaf $\mathbf{A}$ and terminal leaf $\mathbf{B}$ of corn plants 6,10 , and 15 days after inoculation with (1) buffer (healthy), (2) maize dwarf mosaic virus, (3) maize chlorotic mottle virus, or (4) a mixture of the two viruses (corn lethal necrosis). 
nucleoproteins, such as ribosomes, are not. The RNAs released from these nucleoproteins are stable in NaGPS buffer, which is an effective inhibitor of leaf R Nase. MCMV virions were unstable in NaGPS; as much MCMV RNA was found in extracts of infected leaves ground in NaGPS buffer as in those ground in SDScontaining buffer (buffer C) (Fig. 1). Similar results were obtained when purified virus was added to healthy leaves before they were ground, and when purified virus was diluted into NaGPS buffer or buffer C (Fig. 1).

Additional indications that at least a portion of the MCMV virions are unstable were given by the difficulty of scaling up purification procedures and by the repeated observation of two zones in $30-60 \%(\mathrm{w} / \mathrm{v})$ sucrose gradients. Only the lower zone fluoresced in the presence of ethidium bromide, suggesting that it contained swollen, permeable particles. In addition, particles of the lower zone in the sucrose gradient were more thermally labile than those of the upper zone.

\section{DISCUSSION}

Difference of MCMV from sobemoviruses. MCMV has been assigned to the sobemoviruses on the basis of its morphology, molecular weights of RNA and capsid protein, and beetle transmission, in which it resembles the type member, southern bean mosaic virus (SBMV) $(15,29)$. MCMV differs from SBMV in its lack of seed transmission (3).

Our observations indicate additional differences between MCMV and SBMV. The apparent instability of MCMV during purification is unusual for a virus with a high dilution end point $\left(10^{-6}-10^{-8}\right)$ and thermal inactivitation point $(85 \mathrm{C})(15)$. In contrast to the erratic instability of MCMV, SBMV has been the most consistently stable virus worked with in this laboratory. A second, but possibly related difference, is the lower concentration of aromatic amino acids in MCMV than in SBMV. The difference spectrum of SBMV (not shown) indicates that it has more than twice as many aromatic amino acids as MCMV (Fig. 2) or brome mosaic virus (spectrum not shown). For SBMV and brome mosaic virus, this conclusion is supported by published data $(1,13)$. The low concentration of aromatic amino acids in MCMV, shown by inflections at 286 and $295 \mathrm{~nm}$ in the difference spectrum, may contribute to the instability of the virions because aromatic amino acids have been implicated in protein-nucleic acid interactions $(10,16)$. This difference in stability is directly illustrated by the disintegration of MCMV in NaGPS buffer in which SBMV remains intact (7). Finally MCMV differs from SBMV in extinction coefficient (5.8 for SBMV, 6.7 for MCMV), and in percentage of RNA ( $21 \%$ for SBMV, $25 \%$ for MCMV).

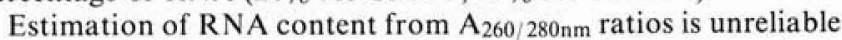
for viruses with low content of aromatic amino acids such as MCMV and brome mosaic virus. The estimation of RNA content of MCMV reported here is based on determinations of virus concentration by dry weight and of separated, hydrolyzed RNA by absorbance.

Effect of disease on chlorophyll. The chlorophyll results (Fig. 5) indicated less reduction than expected from the appearance of the leaves. The terminal leaves of doubly infected plants were bright yellow at 10 and 15 days after inoculations and appeared to have no chlorophyll, but assay showed they had $50 \%$ as much chlorophyll as healthy leaves. Although doubly infected third leaves had mild symptoms they had relatively high concentrations of MCMV (0.6-0.7 mg per gram of tissue) (Figs. 4 and 5) and about a $25 \%$ reduction in chlorophyll.

In contrast, MCMV singly infected terminal leaves developed only mild symptoms late in infection. The chlorophyll assay showed only a $5 \%$ reduction from healthy leaf tissue accompanied by a low virion concentration of less than $0.25 \mathrm{mg}$ per gram (Figs. 4 and 5 ).

At 20 days after inoculation, mild symptoms continue on MCMV-infected leaves, but the doubly infected leaves become necrotic at the tips and the edges and the plants were stunted. MDMV-B maintained a noticeable mosaic through 20 days pBublisbedlintRHYYOPATHOLOGY 77:2 (1987), pp. 162-167.
Effect of mixed infection on virion concentration and rRNA. The effects of dual infection with MCMV and MDMV resembled the results of Rochow and Ross (27) with PVX and PVY. In both systems, there were large increases of one virus (PVX or MCMV) and no corresponding increase of the potyvirus (PVY or MDMVB). The higher concentration of MCMV in the mixed infection could be due either to a higher concentration of virus in each infected cell or to infection of a higher proportion of cells than in a singly infected leaf. If the first hypothesis is correct, then MDMV-B may suppress the regulatory system that normally would limit the concentration of virus in a cell, as suggested by Ross (28). If the second hypothesis is true, then MDMV-B would facilitate movement of MCMV from cell to cell.

It is likely that the increased MCMV concentration accounts for the synergism seen in mixed infections and for the severe symptoms of CLN as compared with the relatively mild symptoms and low concentration (less than $0.4 \mathrm{mg}$ of virus per gram of leaf tissue) of MCMV and MDMV. There was little change in MDMV-B concentration in plants with mixed infection.

Even though leaves of doubly infected plants were yellow 10 days after inoculation and were yellow with necrotic edges 15 days after inoculation (and by then contained about one-third as much viral RNA as total rRNA) there was still relatively little change in their $r$ RNAs. The $23 \mathrm{~S} / 28 \mathrm{~S}$ ratio of $r$ RNA provides information on the differential effects of the disease on chloroplast and cytoplasmic ribosomes and is independent of grinding errors and the number of plant cells per gram of tissue. The primary effect of MCMV infection, either alone or with MDMV-B, does not seem to be on either chloroplast or cytoplasmic ribosomes.

The RNA extraction procedure in a high salt, high $\mathrm{pH}$ buffer allows for rapid and simultaneous analysis of the concentration of MCMV and rRNA on gradients. This assay measures intact genomic RNA (Fig. 3), whereas an assay based on partly purified virions (Fig. 1) measures encapsidated (degraded as well as intact) RNA, and ELISA measures capsid protein whether part of a virion or not. Agreement between these assays may conceivably vary with the stage of infection and environmental conditions which might influence either efficiency of encapsidation or in vivo degradation of the viral RNA.

\section{LITERATURE CITED}

1. Agrawal, H. O. and Tremaine, J. H. 1972. Proteins of cowpea chlorotic mottle, broad bean mottle, and brome mosaic viruses. Virology 47:8-20.

2. Arnon, D. I. 1949. Copper enzymes in isolated chloroplasts. Polyphenoloxidase in Beta vulgaris. Plant Physiol. 24:1-15.

3. Bockelman, D. L., Claflin, L. E., and Uyemoto, J. K. 1982. Host range and seed-transmission studies of maize chlorotic mottle virus in grasses and corn. Plant Dis. 66:216-218.

4. Brakke, M. K. 1963. Photometric scanning of centrifuged density gradient columns. Anal. Biochem. 5:271-283.

5. Brakke, M. K. 1964. Nonideal sedimentation and the capacity of sucrose gradient columns for virus in density-gradient centrifugation. Arch. Biochem. Biophys. 107:388-403.

6. Brakke, M. K. 1971. Wheat streak mosaic virus. No. 48 in: Descriptions of Plant Viruses. Commonw. Mycol. Inst., Assoc. Appl. Biologists, Kew, Surrey, England.

7. Brakke, M. K. 1972. Slowly sedimenting infectious entities of southern bean mosaic virus. Virology 50:669-680.

8. Brakke. M. K. 1979. Ultraviolet absorption spectra and difference spectra of barley stripe mosaic and tobacco mosaic viruses in buffer and sodium dodecyl sulfate. Virology 98:76-87.

9. Brakke, M. K., Ball, E., Hsu, Y.-H., and Joshi, J. 1984. Non-capsid protein associated with wheat streak mosaic virus infection. (Abstr.) Phytopathology 74:860.

10. Burley, S. K., and Petski, G. A. 1985. Aromatic-aromatic interaction: A mechanism of protein structure stabilization. Science 229:23-28.

11. Clark, M. F., and Adams, A. N. 1977. Characteristics of the microplate method of enzyme-linked immunosorbent assay for the detection of plant viruses. J. Gen. Virol. 34:475-483.

12. Diener, T. O. 1962. Isolation of an infectious, ribonuclease-sensitive fraction from tobacco leaves recently inoculated with tobacco mosaic virus. Virology 16:140-146.

13. Ghabrial, S. A., Shepherd, R. J., and Grogan, R. G. 1967. Chemical properties of three strains of southern bean mosaic virus. Virology 
$33: 17-25$.

14. Goldberg, K.-B., and Brakke, M. K. 1985. Concentration of maize chlorotic mottle virus (MCMV) and maize dwarf mosaic virus (MDMV-B) in corn lethal necrosis. (Abstr.) Phytopathology 75:1357.

15. Gordon, D. T., Bradfute, O. E., Gingery, R. E., Nault, L. R., and Uyemoto, J. K. 1984. Maize chlorotic mottle virus. No. 284 in: Descriptions of Plant Viruses. Commonw. Mycol. Inst. Assoc. Appl. Biologists, Kew, Surrey, England.

16. Helene, C., and Maurizot, J. C. 1981. Interactions of oligopeptides with nucleic acids. CRC Crit. Rev. in Biochem. 10:213-258.

17. Hill, J. H., and Benner, H. 1. 1976. Properties of potyvirus RNAs: Turnip mosaic, tobacco etch, and maize dwarf mosaic viruses. Virology 75:419-432,

18. Jensen, S. G. 1985. Laboratory transmission of maize chlorotic mottle virus by three species of corn rootworms. Plant Dis. 69:864-868.

19. Jensen, S. G., Long-Davidson, B., and Seip, L. 1986. Size variation among proteins induced by sugarcane mosaic viruses in plant tissue. Phytopathology 76:528-532.

20. Jensen, S. G., Palomar, M. K., Ball, E. M., and Samson, R. 1985. Factors influencing virus titer in maize dwarf mosaic virus-infected sorghum. Phytopathology 75:1132-1136.

21. Laemmli, U. K. 1970. Cleavage of structural proteins during the assembly of the head of bacteriophage T4. Nature (London) 227:680-685.
22. Lommel, S. A. 1985. Partial characterization of maize chlorotic mottle virus. (Abstr.) Phytopathology 75:1292.

23. Nault, L. R., Styer, W. E., Coffey, M. E., Gordon, D. T., Negi, L. S., and Niblett, C. L. 1978. Transmission of maize chlorotic mottle virus by chrysomelid beetles. Phytopathology 68:1071-1074.

24. Niblett, C. L., and Claflin, L. E. 1978. Corn lethal necrosis-A new virus disease of corn in Kansas. Plant Dis. Rep. 62:15-19.

25. Palomar, M. K., and Brakke, M. K. 1976. Concentration and infectivity of barley stripe mosaic virus in barley. Phytopathology 66:1422-1426.

26. Pirone, T. P. 1972. Sugarcane mosaic virus. No. 88 in: Descriptions of Plant Viruses. Commonw. Mycol. Inst. Assoc. Appl. Biologists, Kew, Surrey, England.

27. Rochow, W. F., and Ross, A. F. 1955. Virus multiplication in plants doubly infected by potato viruses $X$ and $Y$. Virology 1:10-27.

28. Ross, A. F. 1974. Interactions of viruses in the host. Pages 247-260 in: Virus Diseases of Ornamental Plants. R. H. Lawson and M. K. Corbett, eds. Society for Horticultural Science, The Hague, The Netherlands.

29. Tremaine, J. H., and Hamilton, R. 1. 1983. Southern bean mosaic virus. No. 274 in: Descriptions of Plant Viruses. Commonw. Mycol. Inst. Assoc. Appl. Biologists, Kew, Surrey, England.

30. Uyemoto, J. K. 1983. Biology and control of maize chlorotic mottle virus. Plant Dis. 67:7-10. 